\title{
Orthodontic Diagnosis Based on Schwarz Analysis among the Population of Republika Srpska
}

\author{
Adriana Arbutina ${ }^{1}$, Marijana Arapović Savić ${ }^{1}$, Mirjana Umićević Davidović ${ }^{1}$, \\ Irena Kuzmanović Radman² \\ 'University of Banja Luka, Faculty of Medicine, Study Program Dentistry, Department of Orthodontics, Banja Luka, \\ Republika Srpska, Bosnia and Herzegovina; \\ ${ }^{2}$ University of Banja Luka, Faculty of Medicine, Study Program Dentistry, Department of Dental Diseases, Banja Luka, \\ Republika Srpska, Bosnia and Herzegovina
}

\begin{abstract}
SUMMARY
Introduction In order to establish an accurate diagnosis and proper therapy planning in orthodontics, it is necessary to perform the analysis of transverse and sagittal dental arch development in relation to the facial type of the patient. The aim of this study was to determine sagittal and transverse parameters of dental arches in the population of Republika Srpska (Bosnia and Herzegovina) based on Schwarz analysis.

Material and Methods Facial type was determined in 300 patients of both genders, aged 18 to 25 , with class I occlusion. After taking impressions of the upper and lower jaw, cast study models were poured and used to determine basic sagittal and transverse parameters of dental arches. The obtained values were compared with the values defined by Schwarz in order to determine the existence of certain variations.

Results Out of 300 subjects, $50.33 \%$ were dolichofacial, $30.76 \%$ were mesofacial and $19.00 \%$ were brachyfacial. The average values of anterior width, posterior width and height of dental arch in patients with all three types of face showed lower range of values compared to the values defined by Schwarz, who determined his values by examining the same parameters in the population of Vienna. These parameters did not show linear proportional increase with the increase of the sum of upper incisors, what is the case with the values defined by Schwarz.

Conclusion The results of this study showed significant differences compared to Schwarz's values. Modification of the size and shape of dental arch leads to changes in the appearance of patient's face. Therefore, an individual approach during orthodontic diagnosis and treatment planning must be present despite the great importance of biometric standards. Keywords: anterior width; posterior width; arch height; Schwarz's analysis
\end{abstract}

\section{INTRODUCTION}

Orthodontic diagnostics includes various methods to establish a precise diagnosis. Treatment plan and outcome depend on properly implemented methods as they represent proper way to achieve and stabilize functional occlusion, improve aesthetics and quality of patient's life $[1,2]$. Determining dental arch development and its shape has a great clinical importance not only in orthodontics, but also in prosthetics and anthropology. A large number of authors have come to conclusion that dental arch width, measured in premolar and molar region, relates to the meziodistal diameters of upper incisors. Based on this correlation the tables of average values for the width and height of dental arches in different populations have been established $[3,4,5]$.

The first table with the average values of dental arches was created by Pont [6] in 1909 (Pont's Index). Research was conducted on subjects with neutroocclusion who lived in the area of southern France, characterised by brachyfacial type of face. The study conducted by Linder, Harth and Korkhausin in the population of northern
Germany, defined the tables of the average values for the development of dental arches in dolichofacials $[7,8]$.

Orthodontic treatment often includes modification of dental arch form, i.e. width and height of dental arch. It is necessary to use tables of the average values of dental arch parameters. The most commonly used table for our population and average values for anterior and posterior width and height of the dental arch is defined by AM Schwarz. He established the table after doing measurements in mixed Viennese population. Another values were established in Pont's index, however, many authors have found significant differences between the measured values and the average values defined by Pont. Also, studies of different ethnic groups can be useful. Comparing obtained results with average values determines anthropometric characteristics of the population as well as the degree of craniofacial parameters deviation, including the parameters of face and dental arches, which contributes to precise planning of orthodontic treatment $[9,10,11]$.

Studies done in Turkey, based on anthropometric methods, showed significant differences in face types of different populations, as well as sagittal and transversal 
dental arch development in these groups $[12,13]$. Similar results were obtained in research conducted in North America that showed significant differences in transversal dental arch development among subjects of different race [14-17]. Some authors of these studies have used relation between individual parameters of maxillofacial complex, especially width of teeth, dental arches and face, for proper planning of orthodontic and prosthetic treatment.

The aim of this study was to determine sagittal and transverse parameters of upper and lower arches in the population of Republika Srpska (Bosnia and Herzegovina) based on Schwarz analysis.

\section{MATERIAL AND METHODS}

A total of 1,918 male and female were examined, aged 18 to 25. The study was conducted at the Faculty of Medicine in Banja Luka. After orthodontic dental examination, 300 patients were determined to have class I occlusion (neutroocclusion). In patients who met the criteria set (class I occlusion without irregularities that would require orthodontic treatment), using cephalometer, the height and width of face were measured and type of face determined. Then after, the participants were divided into the three groups: brachyfacial (participants with a broad type of face), mesofacial (participants with a medium type of face) and dolichofacial (participant with a narrow type of face). For each subject, preliminary impressions of maxillary and mandibular teeth were taken and study models were poured in gypsum. The analysis of transverse and sagittal dental arch development was carried out on study models using standard procedures. Measurement points were taken from Schwarz's analysis, which is commonly used for diagnostic purposes in our region. Noniusand three-dimensional orthodontic calliper by Korkhaus was used for all measurements.

The following parameters were measured on the study models:
- sum of the upper incisors (SI) - the sum of mesiodistal diameters of upper central and lateral incisors; - anterior width of the upper dental arch -the distance between the deepest distal points of the fissure of first premolars;

- posterior width of the upper dental arch - the distance between the deepest points of the central fissure of first molars;

- height of the upper and lower dental arch - the shortest distance from labial surface of the most prominent incisor to the line which determines the anterior width; - anterior width of the lower dental arch - the distance between the middle of bucco-mesial edges of the second premolars;

- posterior width of the lower dental arch - the distance between bucco-medial cusps of the first permanent molars.

To present anterior and posterior width of the upper and lower dental arch and arch height, descriptive statistics was used. Pearson's parametric correlation was used to correlate results of the current study with the results of Schwarz's analysis.

\section{RESULTS}

For 300 patients with neutroocclusion, the facial type was determined by measuring height and width of the face. $50.33 \%$ of them were determined as dolichofacial, $30.76 \%$ were mesofacial and 19\% were brachyfacial. The results of the anterior width, posterior width and height of the dental arch in all subjects are shown in Tables 1,2, and 3 . In dolichofacial patients, the values for the anterior width had strong positive correlation $(r=0.866 ; \mathrm{p}<0.001)$ with Schwarz's values as well as dental arch height measurements $(\mathrm{r}=0.691 ; \mathrm{p}<0.019)$. Anterior width, posterior width and dental arch height in dolichofacial patients showed significant deviation from Schwarz's results (Table 1).

Table 1. Comparative overview of Schwarz's values for the anterior width, posterior width and height of the dental arch with the same parameters in dolichofacial subjects

Tabela 1. Uporedni prikaz Švarcovih vrednosti za prednju i zadnju širinu i visinu luka s istim parametrima kod ispitanika s uskim tipom lica

\begin{tabular}{|c|c|c|c|c|c|c|}
\hline \multirow{2}{*}{$\begin{array}{c}\text { Sum of incisors } \\
\text { Suma inciziva }\end{array}$} & \multicolumn{5}{|c|}{$\begin{array}{c}\text { Dolichofacial subjects } \\
\text { Uski tip lica }\end{array}$} \\
\cline { 2 - 7 } & $\begin{array}{c}\text { Anterior width } \\
\text { Prednja širina }\end{array}$ & $\begin{array}{c}\text { Values by Schwarz } \\
\text { Švarcove vrednosti }\end{array}$ & $\begin{array}{c}\text { Posterior width } \\
\text { Zadnja širina }\end{array}$ & $\begin{array}{c}\text { Values by Schwarz } \\
\text { Švarcove vrednosti }\end{array}$ & $\begin{array}{c}\text { Dental arch height } \\
\text { Visina zubnog luka }\end{array}$ & $\begin{array}{c}\text { Values by Schwarz } \\
\text { Švarcove vrednosti }\end{array}$ \\
\hline 27.0 & 34.9 & 33.0 & 45.6 & 41.0 & 21.2 & 17.0 \\
\hline 27.5 & 35.0 & 33.5 & 45.6 & 41.5 & 21.2 & 17.5 \\
\hline 28.0 & 35.1 & 34.0 & 45.5 & 42.0 & 21.2 & 17.5 \\
\hline 28.5 & 35.2 & 34.5 & 45.5 & 42.5 & 21.2 & 18.0 \\
\hline 29.0 & 35.3 & 35.0 & 45.4 & 43.5 & 21.2 & 18.5 \\
\hline 29.5 & 35.4 & 35.5 & 45.4 & 44.0 & 21.2 & 18.5 \\
\hline 30.0 & 35.5 & 36.0 & 45.3 & 45.0 & 21.2 & 19.0 \\
\hline 30.5 & 35.8 & 36.5 & 45.5 & 45.5 & 21.3 & 19.0 \\
\hline 31.0 & 36.0 & 37.0 & 45.8 & 46.5 & 21.5 & 19.5 \\
\hline 31.5 & 36.3 & 37.5 & 46.0 & 47.5 & 21.6 & 19.5 \\
\hline 32.0 & 36.6 & 38.0 & 46.2 & 48.0 & 21.7 & 20.0 \\
\hline 32.5 & 37.0 & 38.5 & 46.2 & 48.5 & 21.9 & 20.5 \\
\hline 33.0 & 37.4 & 39.0 & 46.1 & 49.0 & 22.1 & 20.5 \\
\hline
\end{tabular}


Correlation between the values of anterior width, posterior width and height of the dental arch obtained in the current study for mesofacial subjects and Schwarz's results was not statistically significant. The values of anterior width, posterior width and height of the dental arch in mesofacial type had smaller range of values compared to the Schwarz's values (Table 2).

In brachyfacial patients strong correlation $(\mathrm{r}=0.680$; $\mathrm{p}=0.031$ ) was found between the posterior width of dental arch and Schwarz's results, while the value of the anterior width and height of dental arch had no statistically significant correlation with Schwarz's values. The values of the posterior width of dental arch in brachyfacial subjects showed significant deviation from Schwarz's results. For lower values of the sum of incisors, posterior width of dental arch were higher up to $3.5 \mathrm{~mm}$ compared to Schwarz's values, while for higher values of the sum of incisors were smaller up to $7 \mathrm{~mm}$ (Table 3).

\section{DISCUSSION}

In orthodontic practice knowing biometric standards is of great importance and it is the first condition for distinguishing disgnathiae from eugnathia. However, in practice, during diagnosis and treatment planning, errors can happen directly as a result of inadequate use of biometric standards. The current study showed deviation from Schwarz's values for anterior width, posterior width and height of the dental arch in patients with all three types of face. For the sum of incisors $(28,31,32$ and 33) appropriate Schwarz's values are not covered by the intervals of reliability for the average values obtained in the current study.

In dolichofacial subjects, for lower values of the sum of incisors the value of anterior arch width varied from Schwarz's values up to $2 \mathrm{~mm}$, while for higher values of the sum of incisors the values were lower for up to 4.5 $\mathrm{mm}$. For lower values of the sum of incisors, posterior arch

Table 2. Comparison of Schwarz's values for anterior width, posterior width and height of the dental arch with the same parameters in mesofacial subjects

Tabela 2. Uporedni prikaz Švarcovih vrednosti za prednju i zadnju širinu i visinu luka s istim parametrima kod ispitanika sa srednjim tipom lica

\begin{tabular}{|c|c|c|c|c|c|c|}
\hline \multirow{2}{*}{$\begin{array}{c}\text { Sum of incisors } \\
\text { Suma inciziva }\end{array}$} & \multicolumn{5}{|c|}{$\begin{array}{c}\text { Mesofacial subjects } \\
\text { Srednji tip lica }\end{array}$} \\
\cline { 2 - 7 } & $\begin{array}{c}\text { Anterior width } \\
\text { Prednja širina }\end{array}$ & $\begin{array}{c}\text { Values by Schwarz } \\
\text { Švarcove vrednosti }\end{array}$ & $\begin{array}{c}\text { Posterior width } \\
\text { Zadnja širina }\end{array}$ & $\begin{array}{c}\text { Values by Schwarz } \\
\text { Švarcove vrednosti }\end{array}$ & $\begin{array}{c}\text { Dental arch height } \\
\text { Visina zubnog luka }\end{array}$ & $\begin{array}{c}\text { Values by Schwarz } \\
\text { Švarcove vrednosti }\end{array}$ \\
\hline 27.0 & 33.3 & 33.5 & 44.5 & 41.75 & 20.4 & 16.8 \\
\hline 27.5 & 34.0 & 34.0 & 45.0 & 41.25 & 20.4 & 17.0 \\
\hline 28.0 & 34.7 & 34.5 & 45.5 & 42.75 & 20.5 & 17.3 \\
\hline 28.5 & 35.4 & 35.0 & 46.0 & 43.5 & 20.6 & 17.5 \\
\hline 29.0 & 36.1 & 35.8 & 46.5 & 44.5 & 20.6 & 18.0 \\
\hline 29.5 & 36.8 & 36.3 & 47.0 & 45 & 20.7 & 18.0 \\
\hline 30.0 & 37.5 & 37.0 & 47.5 & 46 & 20.8 & 18.5 \\
\hline 30.5 & 37.2 & 37.5 & 47.0 & 46.5 & 21.0 & 18.5 \\
\hline 31.0 & 36.8 & 38.0 & 46.4 & 47.5 & 21.1 & 19.0 \\
\hline 31.5 & 36.5 & 38.5 & 45.9 & 48.5 & 21.3 & 19.0 \\
\hline 32.0 & 36.1 & 39.0 & 45.3 & 49 & 21.5 & 19.5 \\
\hline 32.5 & 36.5 & 39.5 & 45.7 & 49.5 & 21.5 & 19.5 \\
\hline 33.0 & 36.9 & 40.3 & 46.1 & 50.25 & 21.5 & 19.8 \\
\hline
\end{tabular}

Table 3. Comparison of Schwarz's values for the anterior width, posterior width and height of the dental arch with the same parameters in brachyfacial subjects

Tabela 3. Uporedni prikaz Švarcovih vrednosti za prednju i zadnju širinu i visinu luka s istim parametrima kod ispitanika sa širokim tipom lica

\begin{tabular}{|c|c|c|c|c|c|c|}
\hline \multirow{2}{*}{$\begin{array}{c}\text { Sum of incisors } \\
\text { Suma inciziva }\end{array}$} & \multicolumn{5}{|c|}{$\begin{array}{c}\text { Brachyfacial subjects } \\
\text { Široki tip lica }\end{array}$} \\
\cline { 2 - 7 } & $\begin{array}{c}\text { Anterior width } \\
\text { Prednja širina }\end{array}$ & $\begin{array}{c}\text { Values by Schwarz } \\
\text { Švarcove vrednosti }\end{array}$ & $\begin{array}{c}\text { Posterior width } \\
\text { Zadnja širina }\end{array}$ & $\begin{array}{c}\text { Values by Schwarz } \\
\text { Švarcove vrednosti }\end{array}$ & $\begin{array}{c}\text { Dental arch height } \\
\text { Visina zubnog luka }\end{array}$ & $\begin{array}{c}\text { Values by Schwarz } \\
\text { Švarcove vrednosti }\end{array}$ \\
\hline 27.0 & 37.3 & 34.0 & 47.0 & 42.5 & 19.5 & 16.5 \\
\hline 27.5 & 37.2 & 34.5 & 47.0 & 43.0 & 19.7 & 16.5 \\
\hline 28.0 & 37.1 & 35.0 & 47.0 & 43.5 & 19.9 & 17.0 \\
\hline 28.5 & 37.0 & 36.0 & 47.1 & 44.5 & 20.2 & 17.0 \\
\hline 29.0 & 36.9 & 36.5 & 47.1 & 45.5 & 20.4 & 17.5 \\
\hline 29.5 & 36.8 & 37.0 & 47.1 & 46.0 & 20.6 & 17.5 \\
\hline 30.0 & 36.7 & 38.0 & 47.1 & 47.0 & 20.8 & 18.0 \\
\hline 30.5 & 36.9 & 38.5 & 47.0 & 47.5 & 21.0 & 18.0 \\
\hline 31.0 & 37.1 & 39.0 & 46.9 & 48.5 & 21.2 & 18.5 \\
\hline 31.5 & 37.3 & 39.5 & 46.7 & 49.5 & 21.4 & 18.5 \\
\hline 32.0 & 37.5 & 40.0 & 46.6 & 50.0 & 21.6 & 19.0 \\
\hline 32.5 & 37.7 & 41.0 & 46.5 & 50.5 & 21.8 & 19.0 \\
\hline 33.0 & 37.9 & 41.5 & 46.3 & 51.5 & 22.0 & 19.0 \\
\hline
\end{tabular}


width in dolichofacial subjects was higher up to $3 \mathrm{~mm}$ compared to Schwarz's results, while for higher values of the sum of incisors values were lower up to $5 \mathrm{~mm}$. For lower values of the sum of incisors, the height of dental arch in dolichofacial subjects was higher up to $3.5 \mathrm{~mm}$ comparing to Schwarz's results, while for higher values of the sum of incisors it was lower up to $1 \mathrm{~mm}$.

For the values of anterior width, posterior width and height of the dental arch in mesofacial and brachyfacial subjects, significant deviations from Schwarz's values were noticed. Therefore, for higher values of the sum of incisors, the values of anterior width in mesofacial subjects were lower up to $3.5 \mathrm{~mm}$ and the values of posterior width were lower up to $5 \mathrm{~mm}$, while the values of the height of dental arch were higher up to $2 \mathrm{~mm}$. In brachyfacial subjects the values of anterior and posterior width were lower up to $7 \mathrm{~mm}$ compared to Schwarz's values. Also, for higher values of the sum of incisors the arch height values were lower up to $2 \mathrm{~mm}$.

The values obtained for the development of dental arches in transverse and sagittal direction for the subjects in the current study did not show linear proportional increase with the increase of the sum of upper incisors, as it was the case with Schwarz's values. This is in agreement with the results obtained by Thu et al. [16], who analysed width of upper incisors and width of dental arches in Malaysians and noticed that values of anterior and posterior width of dental arches increased with the values of the sum of incisors, but not linearly. They pointed out that some factors, such as gender, ethnicity, face type and muscles, may affect their relation.

Al-Omari et al. [18] also noticed a correlation between the value of the sum of upper incisors and values of anterior and posterior width of upper and lower dental arch. Their research was carried out on 144 patients with neutroocclusion and different facial types, on the territory of Jordan. Their results showed that the values of anterior and posterior width of dental arches were lower than standard values for the same parameters in European population.

Alvaran et al. [19] compared the values of posterior width with Schwarz's values for 473 Colombian patients with all three types of face and noticed that their values were higher from 2.4 to $4.5 \mathrm{~mm}$ than Schwarz's results. The values of posterior width were lower in mesofacial and brachyfacial subjects compared to Schwarz's values while for dolichofacial patients these values were lower only for higher values of the sum of incisors.

Nimkarn et al. [20] examined the possibility of applying Schwarz's analysis to 40 Americans but of European origin and found out that average values of the anterior width by Schwarz were higher from 2.5 to $4.7 \mathrm{~mm}$ compared to their values for all three facial types while the average values of posterior width were higher up to $2 \mathrm{~mm}$ than Schwarz's values.

A significant deviation from Schwarz's values was noted for the height of dental arches, too. Many authors have concluded that there were significant differences in the size of teeth and basic dimensions of dental arches and faces between male and female participants, as well as among patients of different ethnic origin [21-24]. These factors could cause certain deviations of the average values of width and height of dental arches in our participants in relation to the values given by Schwarz's analysis.

\section{CONCLUSION}

The average values for the anterior and posterior width of dental arches in relation to the sum of upper incisors of the tested participants indicated a lower range of values compared to Schwarz's results. Because of these differences and inability to use biometric universal norms, it is necessary to keep an individual approach in planning an adequate orthodontic treatment.

\section{REFERENCES}

1. Proffit WR, Fields HW, Sarver DM. Contemporary Orthodontics. 4th ed. St. Louis, Missouri, USA: Mosby Elsevier; 2007.

2. Graber TM, Vanarsdall RL, Vig KWL. Orthodontics Current Principles and Techniques. 4th ed. Philadelphia, USA: Elsevier Inc.; 2005.

3. Ling JYK, Wong RWK. Dental arch widths of Southern Chinese. Angle Orthodontist. 2009; 79:54-63. Orthodontist. 2009; 79:54-63. [DOl: 10.2319/092007-452.1] [PMID: 19123707]

4. Nötzel F, Schultz C. Leitfaden der Kieferorthopädischen Diagnostik, Analysen und Tabellen für die Praxis. Köln, Deutschland: Deutcher Zahnärtze Verlag; 2009.

5. Purmal K, Alam MK, Moganadas DD, Zakaria NN, Cheong NW. The application and correlation of Pont's Index to the facial framework of three main ethnic groups in Malaysia. Aust Orthod J. 2013; 29:34-42. [PMID: 23785936]

6. Pont A. Der Zahn-Index in der Orthodontie. Z Zahnärztl Orthop. 1909; 3:306-21.

7. Kahl-Nieke B. Einführung in die Kieferorthopädie, Diagnostik, Behandlungsplanning, Therapie. Köln, Deutschland: Deutcher Zahnärtze Verlag; 2009.

8. Knak S. Praxis Leitfaden Kieferorthopädie. München, Deutschland: Urban \& Fischer; 2004.

9. Fang F, Clapham PJ, Chung KC. A Systematic review of interethnic variability in facial dimensions. Plast Reconstr Surg. 2011; 127:874-81. [DOI: 10.1097/PRS.0b013e318200afdb] [PMID: 21285791]

10. Raquel H, Tibana W, Palagi LM, Miguel JA. Changes in dental arch measurements of young adults with normal occlusion - a longitudinal study. Angle Orthod. 2004; 74:618-23. [PMID:15529495]

11. Parahnos LR, Ramos AL, Benedicto EN, Maltagliati LA, Cardoso MA, Filho LC. Is there any association between facial type and mandibular dental arch form with normal occlusion? Acta Scientarium. 2014; 36:129-34. [DOI: 10.4025/actascihealthsci.v3611.17668]

12. Arslan SG, Genc S, Odabas B, Kama JD. Comparison of facial proportions and anthrophometric norms among turkish young adults with different face types. Aesth Plast Surg. 2008; 10:234-42. [DOl: 10.1007/s00266-007-9049-y] [PMID: 17952492]

13. Ozdemir ST, Sigirli D, Ercan I, Simsek Cankur N. Photographic facial soft tissue analysis of healthy Turkish young adults: anthropometric measurements. Aesth Plast Surg. 2009; 33:175-84.

[DOl: 10.1007/s00266-008-9274-z] [PMID: 19089493]

14. Buris BG, Haris EF. Maxillary arch size and shape in American blacks and whites. Angle Orthod. 2000; 70:297-302. [PMID: 10961779]

15. Bayorne M, Sameshima GT, Kim Y, Nojima K, Baek SH, Kook YA. Comparasion of arch forms between Egyptian and North American white populations. Am J Orthod Dentofacial Orthop. 2011; 139:24552. [DOI: 10.1016/j.ajodo.2009.11.012] [PMID: 21392668]

16. Thu KM, Winn T, Abdullah N, Jayasinghen JAP, Chandima GL. The maxillary arch and its relationship to cephalometric landmarks of selected Malay ethnic group. Malays J Med Sci. 2005; 12:29-38. [PMID: 22605945] 
17. Trang VT, Park JH, Bayome M, Shastry S, Mellion A, Kook, YA. Evaluation of arch form between Vietnamese and North American Caucasians using 3 dimensional virtual models. Anthropol Anz. 2015; 72:223-34. [DOI: 10.1127/anthranz/2015/0395] [PMID: 25806820]

18. Al-Omari IK, Duaibis RB, Al-Bitar ZB. Application of Pont's Index to a Jordanian population. Eur J Orthod. 2007; 29:627-31.

[DOl: 10.1093/ejo/cjm067] [PMID: 17971353]

19. Alvaran N, Roldan SI, Buschang PH. Maxillary and mandibular arch widths of Colombians. Am J Orthod Dentofacial Orthop. 2009; 135:649-56. [DOl: 10.1016/j.ajodo.2007.05.023] [PMID: 19409348]

20. Nimkarn Y, Miles PG, O'Reilly M, Weyant R]. The validity of maxillary expansion indices. Angle Orthod. 1995; 65:321-6. [DOI: 10.1043/0003-3219(1995)065<0321:TVOMEI > 2.0.CO;2] [PMID: 8526290]

21. Farkas LG, Katić MJ, Forrest CR, Alt KW, Bagić I, Baltadijev G, et al. International anthropometric study of facial morphology in various ethnic groups/races. J Cranioafac Surg. 2005; 16:615-46. [DOI: 10.1097/01.scs.0000171847.58031.9e] [PMID: 16077306]
22. Smith SS, Buschang PH, Watanabe E. Interarch tooth size relationships of three populations: Does Bolton's analysis apply? Am J Orthod Dentofacial Orthop. 2000; 117:169-74.

[DOl: 10.1016/S0889-5406(00)70228-9] [PMID: 10672217]

23. Fink B, Grammer K, Mitteroecker P, Gunz P, Schaefer K, Bookstein FL, Manning JT. Second to fourth digit ratio and face shape. Proc Biol Sci. 2005; 272:1995-2001.

[DOI: 10.1016/S1090-5138(00)00063-5] [PMID: 16191608]

24. Murmu DC, Acharya SS, Dos AR, Bhaumik B. Evaluation of tooth size and dental arch ratio on Bengali population sample. Orthod J Nepal. 2015; 3:18-21. [DOI: 10.3126/ojn.v312.10072] 


\title{
Primena Švarcove analize u ortodontskoj dijagnostici kod ispitanika Republike Srpske
}

\author{
Adriana Arbutina', Marijana Arapović Savić', Mirjana Umićević Davidović1, Irena Kuzmanović Radman² \\ 'Univerzitet u Banjoj Luci, Medicinski fakultet, Studijski program Stomatologija, Katedra za ortopediju vilica, Banja Luka, \\ Bosna i Hercegovina; \\ Univerzitet u Banjoj Luci, Medicinski fakultet, Studijski program Stomatologija, Katedra za bolesti zuba, Banja Luka, \\ Bosna i Hercegovina
}

\begin{abstract}
KRATAK SADRŽAJ
Uvod Radi postavljanja precizne dijagnoze i pravilnog planiranja ortodontskog lečenja, neophodno je obaviti analizu transverzalne i sagitalne razvijenosti zubnih lukova u odnosu na tip lica pacijenta. Cilj ovog rada je bio da se na osnovu Švarcove (Schwarz) analize utvrdi sagitalna i transverzalna razvijenost zubnih lukova u populaciji Republike Srpske (Bosna i Hercegovina).

Materijal i metode rada Kod 300 ispitanika oba pola, uzrasta od 18 do 25 godina, sa I klasom dentoalveolarnih odnosa određen je tip lica. Nakon uzimanja otisaka gornje i donje vilice izliveni su studijski modeli na kojima su ispitivani osnovni parametri sagitalne i transverzalne razvijenosti zubnih lukova. Dobijene vrednosti su potom upoređivane s vrednostima po Švarcu, kako bi se utvrdila određena odstupanja.

Rezultati Od 300 ispitanika njih 50,33\% je imalo uski tip lica, 30,76\% srednji tip lica, a 19,00\% široki tip lica. Prosečne vrednosti prednje širine, zadnje širine i visine zubnog luka kod ispitanika sa sva tri tipa lica pokazali su manji opseg vrednosti u odnosu na vrednosti do kojih je Švarc došao ispitujući iste parametre kod stanovništva Beča. Navedeni parametri nisu pokazali linearno proporcionalan porast s porastom zbira gornjih inciziva, kao što je to slučaj sa vrednostima po Švarcu.

Zaključak Rezultati ovog istraživanja su pokazali značajna odstupanja u odnosu na Švarcove vrednosti. Modifikacija oblika i dimenzija zubnog luka dovodi do promena u izgledu lica pacijenta, pa je zbog toga neophodan individualni pristup pacijentu tokom postavljanja ortodontske dijagnoze i planiranja lečenja.

Ključne reči: prednja širina; zadnja širina; visina luka; Švarcova analiza
\end{abstract}

\section{UVOD}

Ortodontska dijagnostika obuhvata primenu različitih metoda ispitivanja na osnovu kojih se jasno determiniše dijagnoza. Pravilno odabrane i primenjene metode imaju veliki značaj, jer od njih zavise plan i ishod lečenja, odnosno postizanje stabilne funkcionalne okluzije, poboljšanje estetike lica i unapređenje kvaliteta života pacijenta [1,2].

Određivanje razvijenosti i oblika zubnih lukova je takođe veoma klinički značajno ne samo u ortodonciji, već i u protetici i antropologiji. Veliki broj autora je došao do zaključka da širina zubnog luka, merena u premolarnoj i molarnoj regiji, zavisi od meziodistalnih prečnika gornjih sekutića, pa su na osnovu ove korelacije izrađene tabele prosečnih vrednosti za širinu i visinu zubnih lukova kod različitih populacija $[3,4,5]$.

Prve tabele prosečnih mera zubnog niza izradio je Pont (Pont) [6] 1909. godine (Pontov indeks). Istraživanja je sproveo na ispitanicima sa neutrookluzijom koji su živeli na području južne Francuske, za koje je tipičan široki (euriprozop) tip lica. Istraživanjima koja su sproveli Linder (Linder), Hart (Harth) i Korkhauz (Korkhaus) kod stanovnika severne Nemačke omogućila su pravljenje tabela prosečnih vrednosti za razvijenost zubnih lukova kod uskih (leptoprozop) tipova lica $[7,8]$.

Tokom ortodontskog lečenja često je neophodna modifikacija oblika zubnog luka, a samim tim i širine i visine zubnog luka. Ovde se često koriste tabele prosečnih vrednosti navedenih parametara za određenu populaciju. Za potrebe našeg stanovništva najčešće se koristi tabela prosečnih vrednosti za prednju i zadnju širinu zubnog luka, te visinu zubnog luka po Švarcu, koja je izrađena prema uzorku mešovitog stanovništva grada Beča. Nakon objavljivanja ovog indeksa mnogi autori su testirali njegovu primenu na ispitanicima drugih populacija sa neutrookluzijom i utvrdili da postoje značajna odstupanja iz- merenih vrednosti u odnosu na prosečne vrednosti po Pontu. Takva istraživanja kod različitih etničkih grupa su i danas aktuelna. Poređenjem dobijenih rezultata s prosečnim vrednostima moguće je utvrditi antropometrijske karakteristike populacije određenog područja, odrediti stepen odstupanja kraniofacijalnih parametara, uključujući i parametre lica i zubnih lukova, što doprinosi preciznom planiranju ortodontske terapije $[9,10,11]$.

Istraživanja realizovana na području Turske, zasnovana na antropometrijskim metodama, pokazala su da postoje značajne razlike u tipovima lica različitih populacija, a samim tim i u sagitalnoj i transverzalnoj razvijenosti zubnih lukova kod ispitivanih grupa [12,13]. Do sličnih rezultata se došlo i na osnovu istraživanja izvedenih na teritoriji Severne Amerike, gde je uočeno da postoje značajne razlike u transverzalnoj razvijenosti zubnih lukova između ispitanika različite rasne pripadnosti [14-17]. Pojedini autori ovih studija su povezanost pojedinih parametara maksilofacijalnog kompleksa (posebno širine zuba, zubnih lukova i lica) iskoristili za pravilno planiranje ortodontskog i protetičkog lečenja.

Cilj ovog rada je bio da se na osnovu Švarcove analize utvrdi sagitalna i transverzalna razvijenost zubnih lukova u populaciji Republike Srpske.

\section{MATERIJAL I METODE RADA}

Tokom istraživanja pregledano je ukupno 1.918 ispitanika muškog i ženskog pola, uzrasta od 18 do 25 godina, na Medicinskom fakultetu Univerziteta u Banjoj Luci. Nakon stomatološkoortodontskog pregleda kod 300 ispitanika je utvrđena I klasa dentoalveolarnih odnosa. Kod svih ispitanika koji su zadovoljili postavljene kriterijume (I klasa dentoalveolarnih odnosa bez nepravilnosti koje bi zahtevale ortodontsko lečenje) kefalome- 
trom su izmerene visina i širina lica, te određen tip lica. Nakon toga su ispitanici svrstani u tri grupe: euriprozopi (ispitanici sa širokim tipom lica), mezoprozopi (ispitanici sa srednjim tipom lica) i leptoprozopi (ispitanici sa uskim tipom lica). Svakom ispitaniku je uzet anatomski otisak gornje i donje vilice na osnovu kojih su dobijeni studijski modeli. Na studijskim modelima je obavljena analiza transverzalne i sagitalne razvijenosti zubnih lukova korišćenjem standardnih postupaka. Merne tačke su preuzete iz Švarcove analize, koja se i danas koristi u dijagnostičke svrhe i na ovim prostorima. Merenje je urađeno pomoću dvokrakog ortodontskog šestara i trodimenzionalnog ortodontskog šestara po Korkhauzu.

Na studijskim modelima su izmereni sledeći parametri:

- suma gornjih inciziva (SI) - zbir meziodistalnih prečnika gornjih centralnih i lateralnih sekutića;

- prednja širina gornjeg zubnog luka - rastojanje između distalnih najdubljih tačaka fisure prvih premolara;

- zadnja širina gornjeg zubnog luka - rastojanje između najdubljih tačaka centralne fisure prvih molara;

- visina gornjeg i donjeg zubnog luka - najkraće rastojanje od labijalne površine najisturenijeg sekutića do duži koja određuje prednju širinu;

- prednja širina donjeg zubnog luka - rastojanje između sredina buko-mezijalnih bridova drugih premolara; i

- zadnja širina donjeg zubnog luka - rastojanje između bukosrednjih kvržica prvih stalnih molara.

Za prikaz prednje i zadnje širine gornjeg i donjeg zubnog luka i visine zubnog luka korišćeni su pokazatelji deskriptivne statistike, dok je Pirsonova (Pearson) parametarska korelacija korišćena za utvrđivanje povezanosti rezultata iz ovog istraživanja s rezultatima Švarcove analize.

\section{REZULTATI}

Kod 300 ispitanika sa neutrookluzijom je merenjem visine i širine lica određen indeks lica. Uski tip lica je bio zastupljen kod 50,33\% ispitanika, 30,76\% ispitanika imalo je srednji tip lica, a $19,00 \%$ široki tip lica. Dobijeni rezultati za vrednosti prednje i zadnje širine i visine zubnog luka ispitanika prikazani su u tabelama 1, 2 i 3 . Rezultati ovog istraživanja kod prve grupe ispitanika (s uskim tipom lica) pokazali su da su vrednosti prednje širine u visoko statistički značajnoj i veoma jakoj pozitivnoj korelaciji $(r=0,866 ; p<0,001)$ sa Švarcovim vrednostima, dok su rezultati visine luka u jakoj pozitivnoj korelaciji ( $\mathrm{r}=0,691$; $\mathrm{p}<0,019)$ sa Švarcovim vrednostima. Za prednju širinu, zadnju širinu i visinu zubnog luka kod ispitanika s uskim tipom lica primetno je značajno odstupanje od Švarcovih rezultata (Tabela 1).

Korelacija rezultata prednje i zadnje širine i visine luka ovog istraživanja za srednji tip lica sa Švarcovim rezultatima nije se pokazala statistički značajnom. Vrednosti prednje i zadnje širine i visine zubnog luka za srednji tip lica kod naših ispitanika bile su manjeg opsega vrednosti u odnosu na vrednosti po Švarcu (Tabela 2).

Kod ispitanika sa širokim tipom lica utvrđena je visoko statistički značajna korelacija $(r=0,680 ; p=0,031)$ vrednosti zadnje širine zubnog luka sa Švarcovim rezultatima, dok za vrednosti prednje širine i visine luka korelacija s ovim vrednostima nije imala statistički značaj. Vrednosti zadnje širine zubnog luka kod ispitanika sa širokim tipom lica pokazale su značajno odstupanje od Švarcovih rezultata. Za manje vrednosti sume inciziva, vrednosti za zadnju širinu zubnog luka su bile veće do $3,5 \mathrm{~mm}$ od Švarcovih, dok su za veće vrednosti sume inciziva bile manje i do $7 \mathrm{~mm}$ (Tabela 3).

\section{DISKUSIJA}

U ortodontskoj praksi poznavanje biometrijskih normi je veoma značajno i predstavlja prvi uslov za razlikovanje disgnatije od eugnatije. Međutim, u praksi, prilikom postavljanja dijagnoze i planiranja terapije, često dolazi do grešaka koje direktno proizlaze iz korišćenja neodgovarajućih biometrijskih normi. Tokom ovog istraživanja utvrđeno je da su odstupanja u odnosu na Švarcove vrednosti prednje i zadnje širine i visine luka bile prisutne kod svih grupa ispitanika (sva tri tipa lica). Za veliki broj suma inciziva $(28,31,32$ i 33) odgovarajuće Švarcove vrednosti nisu obuhvaćene intervalima poverenja za prosečne vrednosti dobijene iz ovog istraživanja.

Kod ispitanika s uskim tipom lica, za manje vrednosti sume inciziva vrednosti prednje širine zubnog luka su se razlikovale od Švarcovih vrednosti i do $2 \mathrm{~mm}$, dok su za veće vrednosti sume inciziva dobijene vrednosti bile manje i do $4,5 \mathrm{~mm}$. Za manje vrednosti sume inciziva zadnje širine zubnog luka za uski tip lica su bile veće i do $3 \mathrm{~mm}$ od Švarcovih rezultata, dok su za veće vrednosti sume bile manje i do $5 \mathrm{~mm}$. Za manje vrednosti sume inciziva visine zubnog luka za uski tip lica su bile veće i do 3,5 mm od Švarcovih, dok su za veće vrednosti bile manje do $1 \mathrm{~mm}$.

Za vrednosti prednje i zadnje širine i visine luka kod ispitanika sa srednjim i širokim tipom lica utvrđena su značajna odstupanja u odnosu na Švarcove vrednosti. Tako su za veće vrednosti sume inciziva vrednosti prednje širine za srednji tip lica bile manje do $3,5 \mathrm{~mm}$, a vrednosti zadnje širine do $5 \mathrm{~mm}$, dok su vrednosti visine luka bile veće i do $2 \mathrm{~mm}$. Kod ispitanika sa širokim tipom lica utvrđeno je da su vrednosti prednje i zadnje širine bile manje i do $7 \mathrm{~mm}$ u odnosu na Švarcove vrednosti pri većim vrednostima sume inciziva, a vrednosti visine luka su bile manje i do $2 \mathrm{~mm}$.

Dobijene vrednosti za razvijenost zubnih lukova u transverzalnom i sagitalnom pravcu kod ispitanika u ovom istraživanju nisu pokazale linearno proporcionalan porast s porastom sume gornjih inciziva, kao što je to slučaj s vrednostima po Švarcu. Ovo je u skladu s rezultatima Tua (Thu) i saradnika [16], koji su istražujući povezanost širine gornjih sekutića i širine zubnih lukova kod ispitanika malezijske etničke pripadnosti uočili da se vrednosti prednje i zadnje širine zubnih lukova povećavaju s povećanjem vrednosti sume inciziva, ali da ovaj rast nije linearno proporcionalan. Oni ističu da određeni faktori, kao što su pol, etnička pripadnost, tip lica i muskulatura, mogu uticati na njihovu zavisnost.

Al-Omari (Al-Olmari) i saradnici [18] su takođe uočili povezanost vrednosti sume gornjih inciziva i vrednosti prednje i zadnje širine gornjeg i donjeg zubnog luka. Svoje istraživanje su sproveli na 144 ispitanika sa neutrookluzijom na teritoriji Jordana (sa uskim, srednjim i širokim tipom lica), a rezultati su pokazali da su vrednosti prednje i zadnje širine zubnih lukova manje u odnosu na standardne vrednosti za iste parametre evropske populacije. 
Alvaran (Alvaran) i saradnici [19] su poredeći vrednosti zadnje širine zubnih lukova sa Švarcovim vrednostima kod 473 kolumbijska ispitanika (sa sva tri tipa lica) uočili da su vrednosti u proseku veće 2,4-4,5 mm u odnosu na Švarcove rezultate. U ovom istraživanju vrednosti zadnje širine su bile manje kod ispitanika sa srednjim i širokim tipom lica u odnosu na Švarcove rezultate. Vrednosti zadnje širine kod ispitanika sa uskim tipom lica u ovom istraživanju su takođe bile manje u odnosu na Švarcove, ali samo za veće vrednosti sume inciziva.

Nimkarn (Nimkarn) i saradnici [20] su ispitujući mogućnost primene Švarcove analize na 40 ispitanika, Amerikanaca evropskog porekla, zaključili da su prosečne vrednosti prednje širine zubnih lukova po Švarcu veće u proseku 2,5-4,7 mm u odnosu na vrednosti do kojih su oni došli (za sva tri tipa lica). Prosečne vrednosti zadnje širine u tom istraživanju bile su veće do $2 \mathrm{~mm}$ u odnosu na Švarcove rezultate.

Značajno odstupanje od Švarcovih vrednosti utvrđeno je i kod prosečnih vrednosti za visinu zubnog luka. Veliki broj autora je zaključio da postoje značajne razlike u veličini zuba i osnovnim dimenzijama zubnih lukova i lica između ispitanika muškog i ženskog pola, kao i između ispitanika različite etničke pripadnosti [21-24]. Navedeni faktori bi mogli uzrokovati i utvrđena odstupanja prosečnih vrednosti širine i visine zubnih lukova ispitanika s ovih prostora u odnosu na vrednosti Švarcove analize.

\section{ZAKLJUČAK}

Prosečne vrednosti za prednju i zadnju širinu zubnog luka u odnosu na odgovarajuću sumu gornjih inciziva kod testiranih ispitanika Republike Srpske su ukazali na manji opseg vrednosti u odnosu na Švarcove rezultate. Upravo zbog ovakvih odstupanja i nemogućnosti korišćenja univerzalnih biometrijskih normi, neophodno je zadržati individualni pristup pri planiranju odgovarajuće ortodontske terapije kod svakog pacijenta. 